\title{
New species of the genus Parkiella (Foraminifera) from the Late Cretaceous Central Pacific Ocean: biostratigraphy, biogeography, and the Cretaceous-Palaeogene boundary
}

\author{
JOEN G. V. WIDMARK \& MICHAL KUCERA \\ Department of Marine Geology, Earth Sciences Centre, Göteborg University 41381 Göteborg, Sweden.
}

\begin{abstract}
Two new species, Parkiella angulocamerata sp. nov. and $P$. globocamerata sp. nov., are described from the Late Cretaceous (late Maastrichtian) Central Pacific Ocean, DSDP Sites 465 and 171. Examination under the SEM revealed apertural features that were not documented in the original description of Parkiella. An ' $L$ '-shaped aperture was originally considered as a diagnostic character of Parkiella; we suggest that this is a preservational artefact and question its diagnostic value. The existence of internal toothplates determine both Parkiella described here as members of the family Turrilinidae Cushman 1927. Both species were found to be endemic to the tropical Pacific Ocean. They occurred in sequence throughout the Maastrichtian section at Site 465 with a minimum (one sample) stratigraphic overlap. Parkiella globocamerata is one of the few deep-sea benthic foraminiferal species that indeed became extinct at the Cretaceous/Palaeogene $(\mathrm{K} / \mathrm{Pg})$ boundary. However, we document a decrease in both relative abundance and accumulation rate of the species already prior to the $\mathrm{K} / \mathrm{Pg}$ transition. We propose that the interval between the LO (Last Occurrence) of $P$. angulocamerata and the LO of $P$. globocamerata is indicative of uppermost Cretaceous (Micula prinsii Zone) strata in the tropical Pacific. $J$. Micropalaeontol. 17(1): 51-60, April 1998.
\end{abstract}

\section{INTRODUCTION}

The benthic foraminiferal fauna from the uppermost Cretaceous and lowermost Palaeogene strata at Site 465 (and from the Late Cretaceous of the Central Pacific Ocean in general) has not yet been described in detail - apart from the documentation of the most common taxa by Widmark \& Malmgren (1992a, b) and short communication by Widmark \& Henriksson (1995). In this paper we describe two new species typical for this fauna, discuss their taxonomic position, biostratigraphic significance, and biogeographic distribution.

During a study on benthic foraminiferal changes across the Cretaceous/Palaeogene $(\mathrm{K} / \mathrm{Pg})$ boundary at three DSDP sites, one from the Pacific Ocean (Site 465) and two from the South Atlantic Ocean (Sites 525 and 527), Widmark \& Malmgren (1992a) encountered several taxa that had not been previously described in the literature. Among these was a 'buliminid' species from Site 465 , tentatively named Buliminella? sp. A. This species, here described under the name of Parkiella globocamerata sp. nov. and a probable closely related species, Parkiella angulocamerata sp. nov., are the subjects of the present study.

It has been suggested and later demonstrated that deep-sea benthic foraminifera (as a group) were not severely affected by the biotic crisis at the $\mathrm{K} / \mathrm{Pg}$ boundary (e.g. Douglas \& Woodruff, 1981; Emiliani et al., 1981; Berggren, 1984; Hansen et al., 1987; Thomas, 1990; Nomura, 1991; Kaiho, 1992; Widmark \& Malmgren, 1992a) compared to the vast majority of planktonic organism and shallow benthic groups. Some benthic foraminiferal taxa did, however, respond to this event in that they became extinct or declined drastically in abundance across the $\mathrm{K} / \mathrm{Pg}$ boundary. Buliminella? sp. A. (=Parkiella globocamerata sp. nov.) was among the relatively few taxa that significantly decreased in relative abundance across the $\mathrm{K} / \mathrm{Pg}$ boundary (Widmark \& Malmgren, 1992a). Here, we present a detailed account on its response to the $\mathrm{K} / \mathrm{Pg}$ boundary event in terms of both relative abundances and accumulation rates.

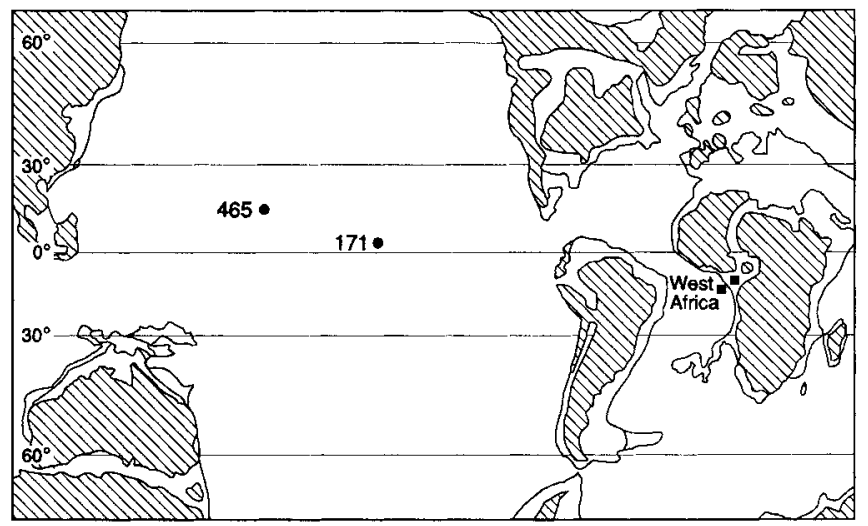

Fig. 1. Known distribution of the genus Parkiella during the Late Cretaceous. Filled circles denote DSDP sites, filled squares denote West African localities (see text).

\section{MATERIAL AND METHODS}

The studied material was obtained from an $84 \mathrm{~m}$ long section including the Maastrichtian, the $\mathrm{K} / \mathrm{Pg}$ boundary, and the lowermost Palaeocene at the Pacific DSDP Site 465 (Hole 465A, southern Hess Rise; Fig. 1, Table 1); a lithostratigraphic column of the section investigated is given in Fig. 2. The upper part of the section (Cores 3-8) consists of foraminifernannofossil chalk and ooze and nannofossil ooze; the $\mathrm{K} / \mathrm{Pg}$ boundary occupies a "mixed zone of Danian and Maastrichtian sediments', approximately $30 \mathrm{~cm}$ thick (Fig. 2A) (Thiede et al., 1981a). Below Core 3, the section is divided by a thick cherty drilling breccia represented by four short cores $(4,6,7,8$; Core 5 is missing) between 67.5 and 105.5 mbsf (Thiede et al., 1981a). The lower part of the sequence (Cores 9-12) consists also of foraminifer-nannofossil ooze and nannofossil ooze and chalk with occasionally higher chert contents (Fig. 2B).

The history of the calcium-carbonate dissolution during the 


\begin{tabular}{lll}
\hline & Site 465 & Site 171 \\
\hline Location & $\begin{array}{l}\text { Southern Hess Rise } \\
\text { (Central Pacific) }\end{array}$ & $\begin{array}{l}\text { Horizon Guyot } \dagger \\
\text { (Central Pacific) } \dagger\end{array}$ \\
Latitude & $34^{\circ} \mathrm{N}^{*}$ & $19^{\circ} \mathrm{N} \dagger$ \\
Longitude & $179^{\circ} \mathrm{E}^{*}$ & $169^{\circ} \mathrm{W} \ddagger$ \\
Water depth & $2161 \mathrm{~m} *$ & $2290 \ddagger$ \\
Palaeolatitude & $13^{\circ} \mathrm{N} \ddagger$ & $20 \mathrm{~N} \ddagger$ \\
Palaeodepth & $1,500 \mathrm{~m} \S$ & $1500 \mathrm{~m} \ddagger$ \\
\hline
\end{tabular}

Table 1. Data on present-day location and water depth, palaeolatitude, and palaeodepth at the end of the Maastrichtian for those DSDP Sites where the genus Parkiella occurred. Figures within parentheses refer to sources of information. References: *Thiede et al. (1981a); $\dagger$ Winterer et al. (1973); $\Varangle$ Thiede et al. (1981b); $\S$ Vallier et al. (1981).

Maastrichtian at Site 465 was studied using the fragmentation of planktonic foraminifera following the method described in Malmgren (1987). Usually more than 300 specimens per sample were counted to determine the proportion of fragments and its precision ( $95 \%$ confidence intervals). Two intervals of strong dissolution ( $>45 \%$ of fragments of planktonic foraminifera) were identified (Fig. 3A). The first interval is represented by one pyrite containing sample in the 'mixed zone' above the $\mathrm{K} / \mathrm{Pg}$ boundary. The second interval (identified in the four lowermost samples from Core 3 ) coincides with the upper range limit of the cherty drilling breccia. Remaining samples are relatively well preserved and the fragmentation of planktonic foraminifera indicates low to moderate calcium carbonate dissolution during their deposition.

Altogether 31 samples from Hole 465A were analysed with a closer sampling towards the $\mathrm{K} / \mathrm{Pg}$ boundary in order to obtain a higher resolution at this transition (Table 2). The samples were immersed in de-ionized water and placed on a rotary table for about $24 \mathrm{~h}$. They were washed over a $63 \mathrm{~mm}$ sieve; both fractions were dried and (in most cases) weighed. The sand fraction was then sieved over a $125 \mathrm{~mm}$ screen, and the larger fraction was used for generation of compositional data. A total of 101 specimens (84 complete and 17 broken) of Parkiella spp. nov. were encountered at Site 465 and additionally 40 specimens (22 complete and 18 broken) from DSDP Site 171 (Horizon Guyot; Fig. 1, Table 1) were available for an account on the geographic distribution of the genus Parkiella during the Maastrichtian. A list of the samples analysed (with respect to sample depths, weight, and number of Parkiella spp. nov. specimens per sample) is given in Table 2.

A sedimentation model was established for the upper part (61.84-64.90 mbsf; Core 3) of the studied section from Site 465. Estimates of sedimentation rates are based on the assumption of a duration of about $0.2 \mathrm{~m} . \mathrm{y}$. for the calcareous nannofossil Micula prinsii Zone and $0.3 \mathrm{~m}$.y. for the plank tonic foraminiferal 'Globigerina' eugubina Zone (Berggren et al., 1985; Henriksson, 1993) (Table 3). The accumulation rate (number of specimens/ $\mathrm{kyr} / \mathrm{cm}^{2}$ ) was used to visualize the changes in abundance of $P$. globocamerata $\mathrm{sp}$. nov. across the $\mathrm{K} / \mathrm{Pg}$ boundary. It approximates a measure of population density and does not depend on fluctuations in abundances of other species within the rest of the benthic foraminiferal fauna. The number of specimens $/ \mathrm{kyr} / \mathrm{cm}^{2}$ was calculated as $D^{*} N^{*} S$, where $D$ is the density of the sediment (set to $1.925 \mathrm{~g} / \mathrm{cm}^{3}$ in this study), $N$ is the number of specimens per gram sediment and $S$ is the sedimentation rate in $\mathrm{cm} / \mathrm{kyr}$ as given in Table 3.

\begin{tabular}{|c|c|c|c|c|c|c|c|c|}
\hline $\begin{array}{l}\text { Sample } \\
\text { No. }\end{array}$ & Hole & $\begin{array}{l}\text { Core } \\
\text { sec. }\end{array}$ & $\begin{array}{l}\text { Interval } \\
(\mathrm{cm})\end{array}$ & $\begin{array}{l}\text { Depth } \\
\text { (mbsf) }\end{array}$ & Zone & $\begin{array}{l}\text { Weight } \\
(\mathrm{g})\end{array}$ & B & $\mathrm{N}$ \\
\hline 1 & $465 \mathrm{~A}-$ & $3-3$ & $84-85$ & 61.84 & Geu & 3.61 & 906 & 0 \\
\hline 2 & $465 \mathrm{~A}-$ & $3-3$ & $99-100$ & 61.99 & Geu & 3.61 & 779 & 0 \\
\hline 3 & $465 \mathrm{~A}-$ & $3-3$ & $120-122$ & 62.21 & Mixed & 3.35 & 326 & 2 \\
\hline 4 & $465 \mathrm{~A}-$ & $3-3$ & $130-132$ & 62.31 & Mixed & 4.30 & 222 & 1 \\
\hline 5 & $465 \mathrm{~A}-$ & $3-3$ & $139-140$ & 62.39 & Mixed & 2.42 & 202 & 1 \\
\hline $\mathrm{K} / \mathrm{Pg}$ & & & & 62.43 & & & & \\
\hline 6 & $465 \mathrm{~A}-$ & $3-3$ & $148-149$ & 62.48 & Abm & 3.22 & 317 & 2 \\
\hline 7 & $465 \mathrm{~A}-$ & $3-4$ & $4-5$ & 62.54 & Abm & 4.41 & 435 & 4 \\
\hline 8 & $465 \mathrm{~A}-$ & $3-4$ & $12-13$ & 62.62 & Abm & 1.77 & 157 & 3 \\
\hline 9 & $465 \mathrm{~A}^{-}$ & $3-4$ & $20-22$ & 62.71 & $\mathrm{Abm}$ & 2.29 & 192 & 2 \\
\hline 10 & $465 \mathrm{~A}-$ & $3-4$ & $30-31$ & 62.80 & Abm & 3.66 & 370 & 3 \\
\hline 11 & $465 \mathrm{~A}-$ & $3-4$ & $40-41$ & 62.90 & $\mathrm{Abm}$ & 4.22 & 481 & 3 \\
\hline 12 & $465 \mathrm{~A}-$ & $3-4$ & $61-62$ & 63.11 & Abm & 4.58 & 389 & 5 \\
\hline 13 & $465 \mathrm{~A}-$ & $3-4$ & $79-80$ & 63.29 & $\mathrm{Abm}$ & 3.61 & 445 & 3 \\
\hline 14 & $465 \mathrm{~A}-$ & $3-4$ & $100-101$ & 63.50 & Abm & 3.08 & 263 & 0 \\
\hline 15 & $465 \mathrm{~A}-$ & $3-4$ & $140-142$ & 63.91 & $\mathrm{Abm}$ & 3.66 & 401 & 10 \\
\hline 16 & $465 \mathrm{~A}-$ & $3-5$ & $30-32$ & 64.31 & $\mathrm{Abm}$ & 6.68 & 894 & 20 \\
\hline 17 & $465 \mathrm{~A}-$ & $3-5$ & $89-91$ & 64.90 & $\mathrm{Abm}$ & 5.96 & 446 & 8 \\
\hline 18 & $465 \mathrm{~A}-$ & $3-6$ & $10-12$ & 65.62 & Abm & & 449 & 6 \\
\hline 19 & $465 \mathrm{~A}^{-}$ & $3-6$ & $19-21$ & 65.71 & Abm & & 348 & 5 \\
\hline 20 & $465 \mathrm{~A}-$ & $3-6$ & $59-60$ & 66.10 & ? Abm & 6.39 & $-\ldots$ & \\
\hline 21 & $465 \mathrm{~A}-$ & $3-6$ & $64-65$ & 66.15 & Abm & 6.06 & 391 & 7 \\
\hline 22 & $465 \mathrm{~A}^{-}$ & $3 \mathrm{cc}$ & $9-10$ & 66.30 & $\mathrm{Abm}$ & 4.80 & 119 & 20 \\
\hline 23 & $465 \mathrm{~A}-$ & $7 \mathrm{cc}$ & $0-2$ & 97.52 & Gico & & - & - \\
\hline 24 & $465 \mathrm{~A}-$ & $8 \mathrm{cc}$ & $0-2$ & 105.82 & Gco & & 248 & 0 \\
\hline 25 & $465 \mathrm{~A}-$ & $9-1$ & $0-8$ & 115.08 & Gga & & 237 & 0 \\
\hline 26 & $465 \mathrm{~A}-$ & $9 \mathrm{cc}$ & $0-2$ & 123.62 & Gga & & 186 & 0 \\
\hline 27 & $465 \mathrm{~A}-$ & $10-3$ & $0-2$ & 127.52 & Gga & & 365 & 6 \\
\hline 28 & $465 \mathrm{~A}-$ & $11-2$ & $0-2$ & 135.52 & Gsc & & 537 & 8 \\
\hline 29 & $465 \mathrm{~A}-$ & $11-5$ & $0-2$ & 140.02 & Gsc & & 402 & 9 \\
\hline 30 & $465 \mathrm{~A}-$ & $12-1$ & $38-40$ & 143.90 & Gsc & & 351 & 5 \\
\hline 31 & $465 \mathrm{~A}-$ & $12 c c$ & $0-2$ & 145.72 & Gsc & & 395 & 0 \\
\hline 32 & $171-$ & $9-5$ & 748 & 154.88 & Abm & & 335 & 22 \\
\hline 33 & $171-$ & $11-5$ & $110-124$ & 173.24 & ?Gga & & 190 & 18 \\
\hline
\end{tabular}

Table 2. Data for DSDP samples used in the present study. 'Weight' is total dry sample weight, ' $N$ ' is the number of Parkiella spp. nov. specimens encountered in each sample, and ' $B$ ' is the total number of benthic foraminifera in samples. 'Zone' refers to planktonic foraminifera zones as identified by Boersma (1981). Sample 20 was barren of foraminifera, and sample 23 was not included in the study due to poor preservation. $\mathrm{K} / \mathrm{Pg}$ denotes the Cretaceous-Palaeogene boundary. Zone abbreviations: Geu = 'Globigerina' eugubina; Mixed = 'mixed zone' of Maastrichtian and Danian sediments, $\mathrm{Abm}=$ Abathomphalus mayaroensis; $\mathrm{Cco}=$ Globotruncana contusa; $\mathrm{Gga}=$ Globotruncana gansseri; Gsc $=$ Globotruncana scutilla

\section{SYSTEMATIC DESCRIPTIONS}

The genus Parkiella was recently established by Seiglie et al. (1993) on the type species Buliminella gabonica de Klasz and Rérat, 1962. It includes a group of morphologically distinct species described from Upper Cretaceous shelf deposits from West Africa (Cameroon and Gabon) by de Klasz \& Rérat (1962) and de Klasz et al. (1963). The diagnosis of Parkiella is based on its 'low trochospiral coil' and 'complex ' $L$ '-shaped aperture' (Seiglie et al., 1993). These characteristics together with the generally lower number of chambers/whorl separate Parkiella from Buliminella Cushman 1927 and Praebulimina Hofker 1957 according to Seiglie et al. (1993). Other turrillinid genera, such as Sporobulimina Stone 1949 and Sporobuliminella Stone 1949 (both possess supplementary apertures) and Sitella Voloshina 1974 (with an inverted 'T'-shaped aperture), are separated from 

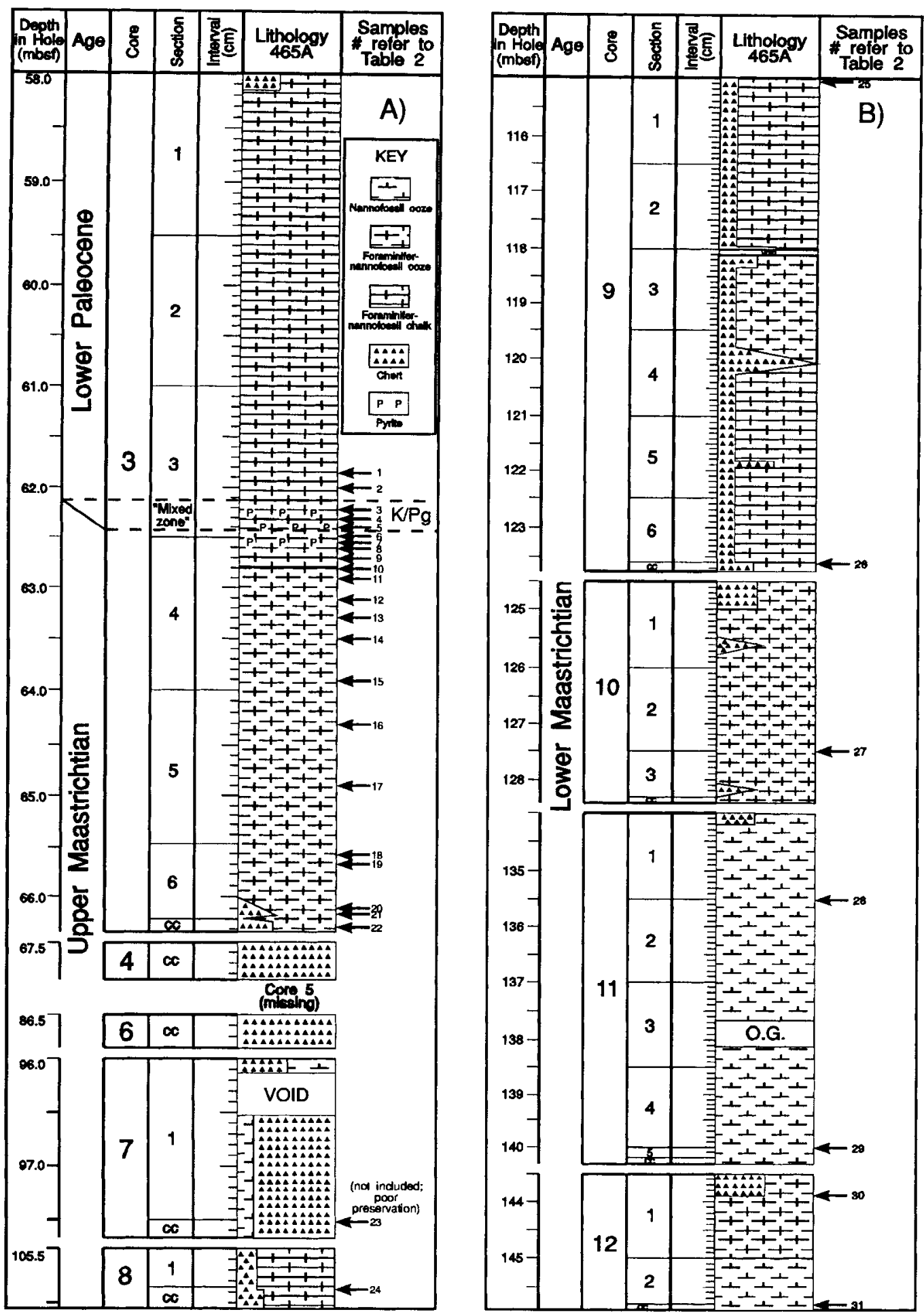

Fig. 2. Lithology, depth in Hole (metres below sea floor [mbsf]), and sampling of the section studied at Site 465 (Hole 465A); (A) Cores 3-8; (B) Cores 9-12. Figure modified after Thiede et al. (1981a). 


\section{Site 465}
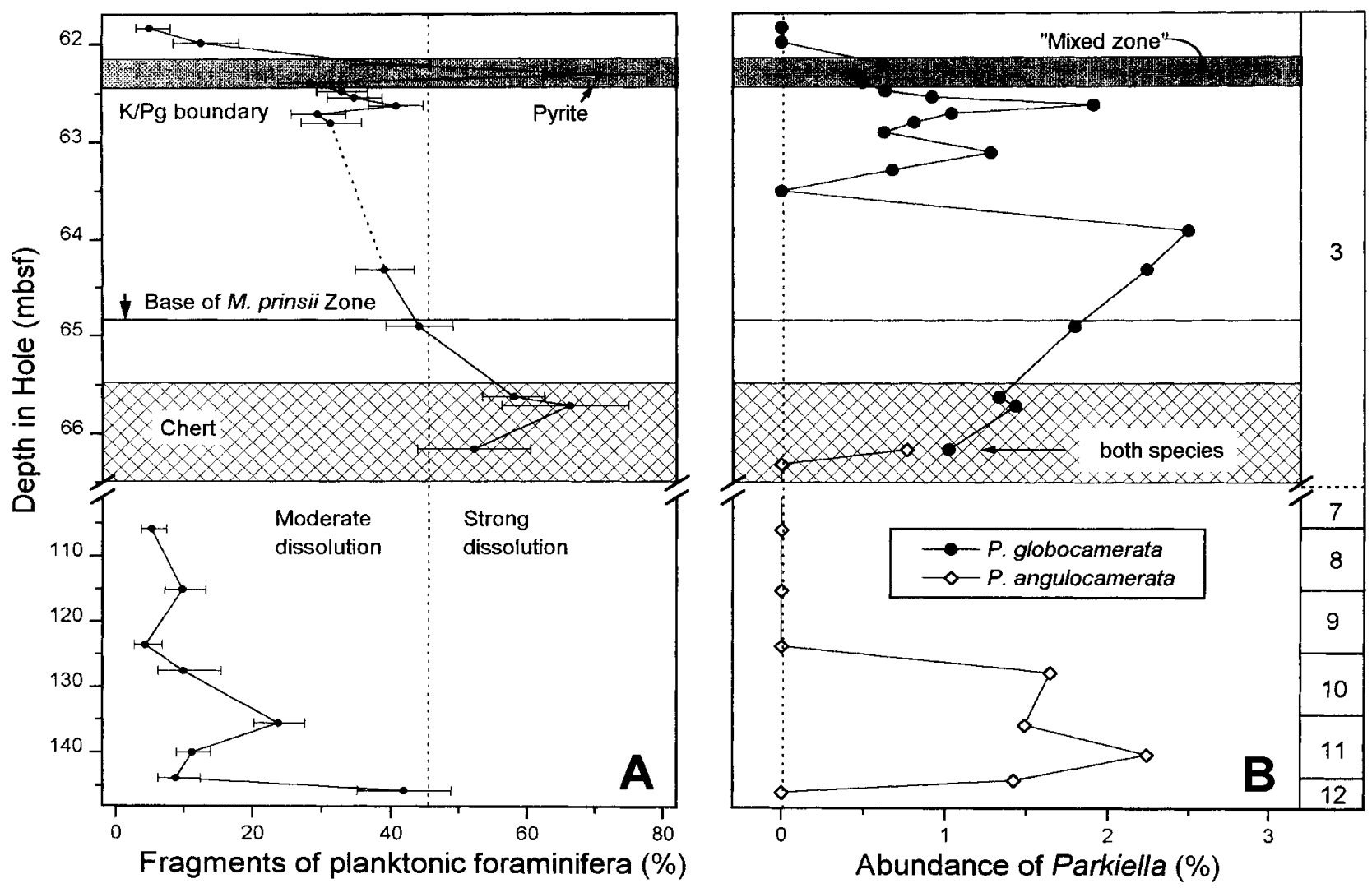

Fig. 3. (A) Calcium carbonate dissolution history at Site 465 in terms of planktonic foraminiferal fragmentation; note that two intervals of strong dissolution were detected, one coinciding with the thick chert (drilling breccia) and the other (represented by one sample only) associated with the pyrite containing layer at the $\mathrm{K} / \mathrm{Pg}$ boundary. Horizontal bars represent $95 \%$ confidence intervals. (B) The relative abundance (\%) of Parkiella spp. nov.; note that $P$. angulocamerata sp. nov. is succeeded by $P$. globocamerata sp. nov. with a minimum of stratigraphic overlap (one sample only). Cores 4-7 were omitted in both figures; vertical scale changes below Core 3 .

$\mathrm{K} / \mathrm{Pg}$ boundary

Top ' $G$ '. eugubina Zone*

Base $M$. prinsii Zone*

Base $M$. murus Zone*

Estimated sedimentation rate above the $\mathrm{K} / \mathrm{Pg}$ boundary

Estimated sedimentation rate below the $\mathrm{K} / \mathrm{Pg}$ boundary

$$
\begin{array}{r}
62.44 \mathrm{mbsf} \dagger \\
+1.2 \mathrm{~m} \ddagger \\
-2.3 \mathrm{~m} \S \\
-9.94 .8 \mathrm{~m} \\
0.4 \mathrm{~cm} / \mathrm{kyr} \\
1.2 \mathrm{~cm} / \mathrm{kyr}
\end{array}
$$

Table 3. Biostratigraphic data upon which the age model for Core 3 , Hole 465A was established (see also Widmark \& Malmgren, 1992a). * meters below/above the $\mathrm{K} / \mathrm{Pg}$ boundary. †Thiede et al. (1981a); $\ddagger$ Boersma \& Shackleton (1981); § Henriksson (1993); Cepek (1981).

Parkiella on the basis of apertural characteristics (Seiglie et al., 1993). Seiglie et al. (1993) found it problematic, however, to place Parkiella in a higher systematic category, since the specimens in their well samples were completely replaced by pyrite or completely pyrite infilled, which made it impossible to observe any internal apertural features. Nevertheless, based on the 'mophological characteristics' alone, Seiglie et al. (1993) placed Parkiella in the Turrilinidae Cushman 1927. The main argument for this allocation was that a taxon with such morphological characteristics would possess a toothplate and, therefore, should be placed in Turrilinidae (Seiglie et al., 1993).

A close examination under the SEM elucidated some new apertural features in our Parkiella species. Well preserved apertures were found to be equipped with a delicate apertural flap (Fig. 4G), which covers an analogue of the periapertural depression as in Bulimina (see Verhallen, 1986). In addition, an apertural lip (Fig. 4B-C, G-H) is present in most specimens. The apertural flap is, however, often broken off as shown in Fig. $4 \mathrm{~B}-\mathrm{C}, \mathrm{H}-\mathrm{I}$. In even worse preserved specimens the aperture is excavated along the basal suture of the last chamber into an ' $\mathrm{L}$ '. shaped opening (Fig. 4C, H-I); sometimes even the apertural lip is destroyed by postmortal processes (Fig. 4I). These ' $L$ '-shaped openings observed in both species described here is, hence, a preservational artefact. Although we did not have the possibility to examine the type material of Parkiella, the validity of this character as diagnostic of this genus has to be questioned. 


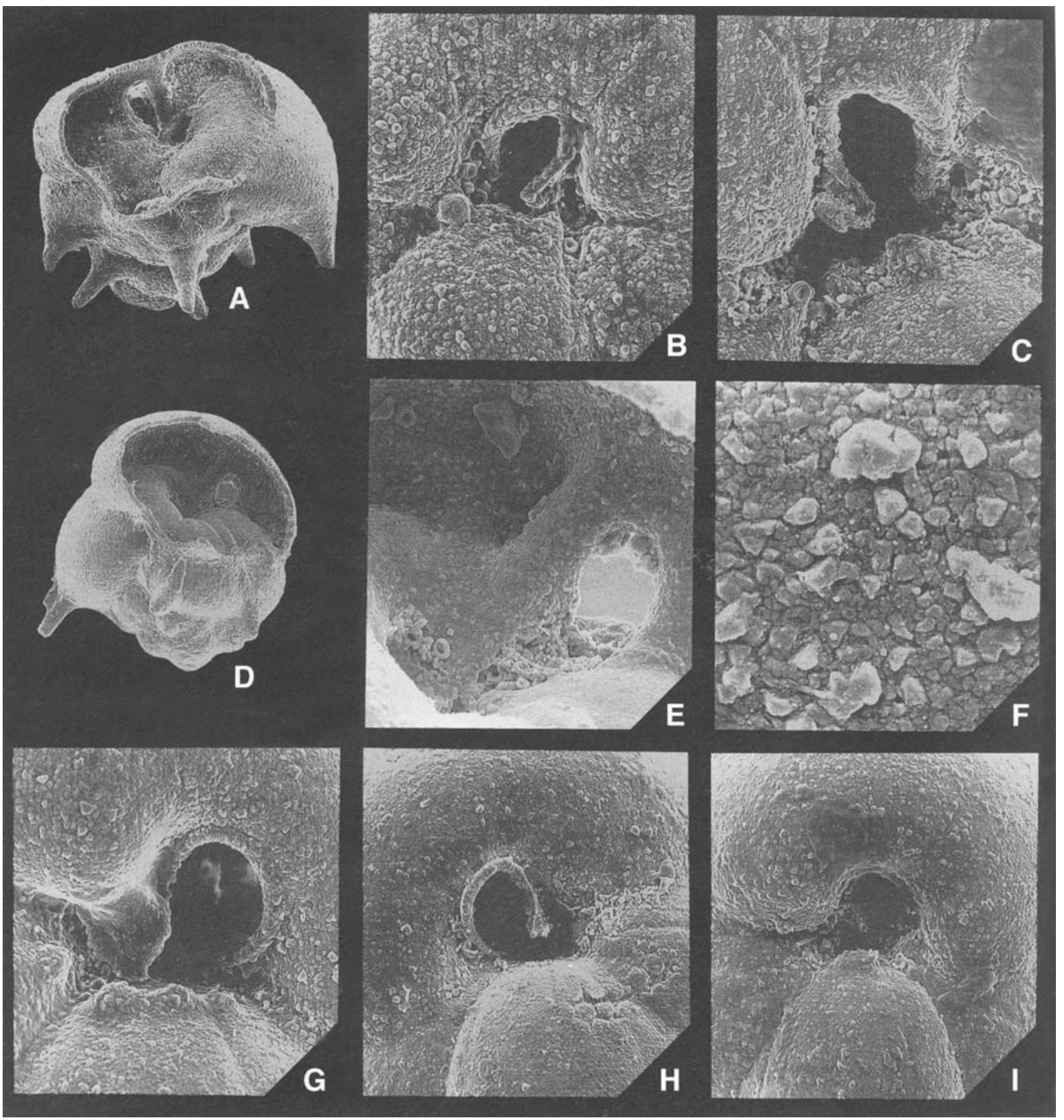

Fig. 4. SEM micrographs of Parkiella angulocamerata sp. nov. (A-C) and Parkiella globocamerata sp. nov. (D-I) showing taxonomic features discussed in text. (A) Specimen with last chamber removed showing toothplate between successive apertures (sample $465 \mathrm{~A}-11-5,0-2 \mathrm{~cm}$; $\times 230)$. (B) Aperture where apertural flap is broken off (sample 465A-10-3, 0-2 cm; $\times 760$ ). (C) Aperture excavated along basal suture of final chamber into a ' $L$ 'shaped opening (sample 465A-11-5, 0-2 cm; $\times 1000$ ). (D) Specimen with last chamber removed to show toothplate between successive apertures (sample 465A-3-5, 30-32 cm; $\times 200$ ). (E) Detail showing the toothplate between successive apertures in Fig. 4D $(\times 780)$. (F) Wall structure, showing fine pores surrounded by about six radially arranged calcite crystals (sample 465A-3-5, 89-9l cm; $\times 5000$ ). (G) Well preserved aperture with apertural flap (sample 465A-3-5, 89-91 cm; $\times 790)$. (H) Less well preserved aperture where apertural flap is broken off and the excavation along basal suture is initiated (sample 465A-3-4, 140-142 cm; $\times 570$ ). (I) poorly preserved aperture where both apertural flap and apertural lip are destroyed by postmortal processes and the excavation along basal suture forms a ' $L$ '-shaped opening (sample $465 \mathrm{~A}-3-4,79-80 \mathrm{~cm}$; $\times 550$ ).

In order to examine the internal apertural features of our Parkiella spp. nov., the last chambers in specimens of each species were removed (Fig. 4A, D). Both species exhibit a short internal toothplate, which connects the 'periapertural depressions' of successive chambers (Fig. 4A, D-E). The presence of a toothplate in our Parkiella spp. nov. determines them to be placed in the family Turrilinidae and supports the relationship between such apertural features and 'turrilinid test-morphologies' as suggested by Seiglie et al. (1993).

The finely perforate wall structure of $P$. globocamerata $\mathrm{sp}$. nov. is demonstrated in Fig. 4F; each pore seems to be surrounded by six radially arranged calcite crystals. No distinct dimorphism in terms of micro- and macrospheres could be observed in either of the species described herein. 

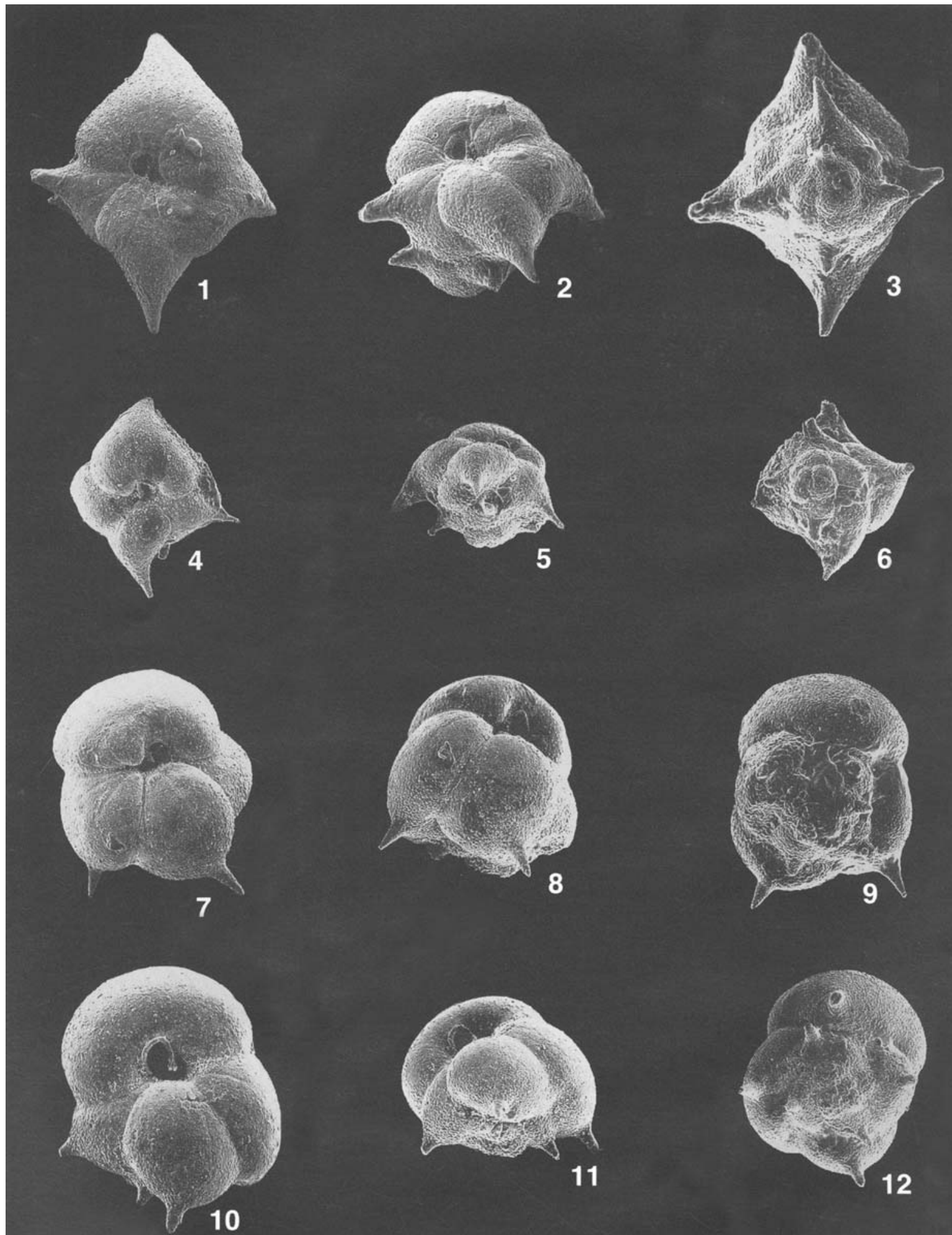

\section{Explanation of Plate 1}

Figs 1-6. Parkiella angulocamerata sp. nov. (sample 465A-11-2, 0-2 cm; all $\times 200$ ). fig. 1, holotype, apertural view. fig. 2, holotype, side view. fig. 3, holotype, apical view. fig. 4, paratype, apertural view. fig. 5, paratype, side view. fig. 6, paratype, apical view. figs 6-12. Parkiella globocamerata sp. nov. (sample 465A-3-4, 140-142 cm; all $\times 200$, except fig. 10: $\times 250$ ). fig. 7, holotype, apertural view. fig. 8 , holotype, side view. fig. 9 , holotype, apical view. fig. 10, paratype, apertural view. fig. 11, paratype, side view. fig. 12, paratype, apical view. 


\author{
Class Foraminifera Lee, 1990 \\ Order Rotaliida Lankester, 1885 \\ Superfamily Turrilinacea Cushman, 1927 \\ Family Turrilinidae Cushman, 1927 \\ Genus Parkiella Seiglie, Haman \& Baker, 1993 \\ Parkiella angulocamerata sp. nov.
}

(Pl. 1, figs 1-6)

Derivation of name. Refers to the angular shape of chambers.

Diagnosis. Test subpyramidal, subquadrate in section, chambers quadriserially arranged and pointed, gradually converting into long spines.

Type material. Holotype (Pl. 1, figs 1-3) and one paratype (Pl. 1, figs 4-6). Primary types deposited at the Cushman Collection, National Museum of Natural History, Smithsonian Institution, Washington DC, USA, and filed under the following museum catalogue numbers: USNM 489216 (holotype) and USNM 489217 (paratype).

Material. Thirty-one (26 complete and five fragmented) specimens from DSDP Site 465 (Hole 465A) and 36 (20 complete and 16 fragmented) specimens from DSDP Site 171 (Hole 171).

Locality and type level. Pacific Ocean, southern Hess Rise, Lower Maastrichtian, Globotruncana scutilla Zone, DSDP sample 465A-11-2, 0-2 cm.

Description. Test tapering, subpyramidal, and quadrate in section. Chambers quadriserially arranged in three-to-four whorls, four pointed chambers/whorl; chambers gradually convert into long spines (chambers of initial whorl lack spines); proloculus visible and globular. Sutures distinct and slightly depressed. Walls calcareous (hyaline) and finely perforate. Aperture forming a loop extending from base of last chamber up apertural face; aperture possessing a lip and an internal toothplate; an apertural flap may be observed in well preserved specimens; poorly preserved specimens often exhibit apertures excavated into an 'L'-shaped opening.

Dimensions. Holotype: maximum diameter $0.30 \mathrm{~mm}$ without spines $(0.38 \mathrm{~mm}$ including spines), height $0.21 \mathrm{~mm}$; paratype: maximum diameter $0.19 \mathrm{~mm}$ without spines $(0.23 \mathrm{~mm}$ including spines), height $0.13 \mathrm{~mm}$.

Remarks. This curious species is well distinguished from its stratigraphic successor $P$. globocamerata sp. nov., which possesses a compact, low trochospiral test with inflated chambers instead of the subpyramidal, tapering test with pointed chambers (that gradually convert into long spines) of $P$. angulocamerata sp. nov. None of the West African species of the genus Parkiella ( $P$. gabonica [de Klasz \& Rérat], $P$. brevispira [de Klasz, Magné, \& Rérat], and $P$. mamelligera Klasz \& Rérat]) possess the characteristic pointed chambers with long spines.

Parkiella globocamerata sp. nov.

$$
\text { (Pl. 1, figs 7-12) }
$$

1973 Buliminella sp. Douglas: 634, pl. 7, fig. 6.

1992 Buliminella? sp. Widmark \& Malmgren: 111, pl. 4, fig. 4. Derivation of name. Refers to the globular shape of chambers. Diagnosis. Test low trochospiral, subcircular in section, chambers inflated, equipped with a distinct slender short spine.

Type material. Holotype (Pl. 1, figs 7-9) and one paratype (Pl. 1, figs 10-12). Primary types deposited at the Cushman Collection, National Museum of Natural History, Smithsonian Institution, Washington DC, USA, and filed under the following museum catalogue numbers: USNM 489218 (holotype) and USNM 489219 (paratype).

Material. Eighty-four (62 complete and 12 fragmented) specimens from DSDP Site 465 (Hole 465A) and four (two complete and two fragmented) specimens from DSDP Site 171 (Hole 171). Locality and type level. Pacific Ocean, southern Hess Rise, Upper Maastrichtian, Micula prinsii Zone, DSDP sample 465A$3-4,140-142 \mathrm{~cm}$.

Description. Test compact, subglobular, and subcircular in section. Chambers arranged in a low trochospiral coil of three whorls, three-to-four subglobular (inflated) chambers/whorl; chambers equipped with a distinct slender short spine (except in chambers of initial whorl); proloculus visible and globular. Sutures distinct and slightly depressed. Wall calcareous (hyaline) and finely perforate. Aperture forming a loop extending from base of last chamber up apertural face; aperture possessing a lip and a internal toothplate; an apertural flap may be observed in well preserved specimens; poorly preserved specimens often exhibit apertures excavated into an ' $\mathrm{L}$ '-shaped opening.

Dimensions. Holotype: maximum diameter $0.29 \mathrm{~mm}$ without spines $(0.35 \mathrm{~mm}$ including spines), height $0.19 \mathrm{~mm}$; paratype: maximum diameter $0.24 \mathrm{~mm}$ without spines $(0.27 \mathrm{~mm}$ including spines), height $0.16 \mathrm{~mm}$.

Remarks. This form differs from its stratigraphic precursor $P$. angulocamerata $\mathrm{sp}$. nov. in the chamber arrangement, in possessing more inflated chambers (that abruply end in distinct spines), and in a subcircular rather than quadrate transection. Parkiella gabonica (de Klasz \& Rérat) and $P$. brevispira (de Klasz, Magné, \& Rérat) do not possess spines; $P$. mamelligera (de Klasz \& Rérat) possesses a larger test, much shorter 'spines', and a higher number of chambers/whorl (four-to-five instead of three-to-four in $P$. globocamerata sp. nov.).

\section{BIOSTRATIGRAPHIC DISTRIBUTION AND THE K/PG BOUNDARY}

Parkiella angulocamerata sp. nov. and $P$. globocamerata sp. nov, occurred in sequence throughout the studied section at Site 465 (Table 2) with almost no overlap in their respective vertical ranges. Parkiella angulocamerata was found in the lower part, whereas $P$. globocamerata was encountered in the upper part of the sequence.

The lower range limit of $P$. angulocamerata sp. nov. could not be satisfactorily determined due to insufficient sampling and recovery below Core 12 . Sample no. 30 represents the lowermost level, at which the species was found; no specimens of the species were encountered below that level, either in the lowermost part of Core 12 (sample no. 31), or in the chert drilling breccia from Core 14 during a preliminary survey of sample $465 \mathrm{~A}-14 \mathrm{cc}, 0-$ $2 \mathrm{~cm}$. The uppermost sample containing $P$. angulocamerata $\mathrm{sp}$. nov. (sample no. 21) also contains the lowermost specimens of $P$. globocamerata sp. nov., which indicates that both species may have lived at the same time.

Parkiella globocamerata sp. nov. was found in samples from the interval between the upper limit (sample no. 21) of the $38.6 \mathrm{~m}$ thick chert and the 'mixed zone' at the K/Pg boundary (sample no. 3). The lower range limit of $P$. globocamerata $\mathrm{sp}$. nov. lies between the bottom of Core 3 and the top of Core 10. No specimens of Parkiella were found in this $60 \mathrm{~m}$ thick interval; Cores 4-7 are characterized by high chert content resulting in 


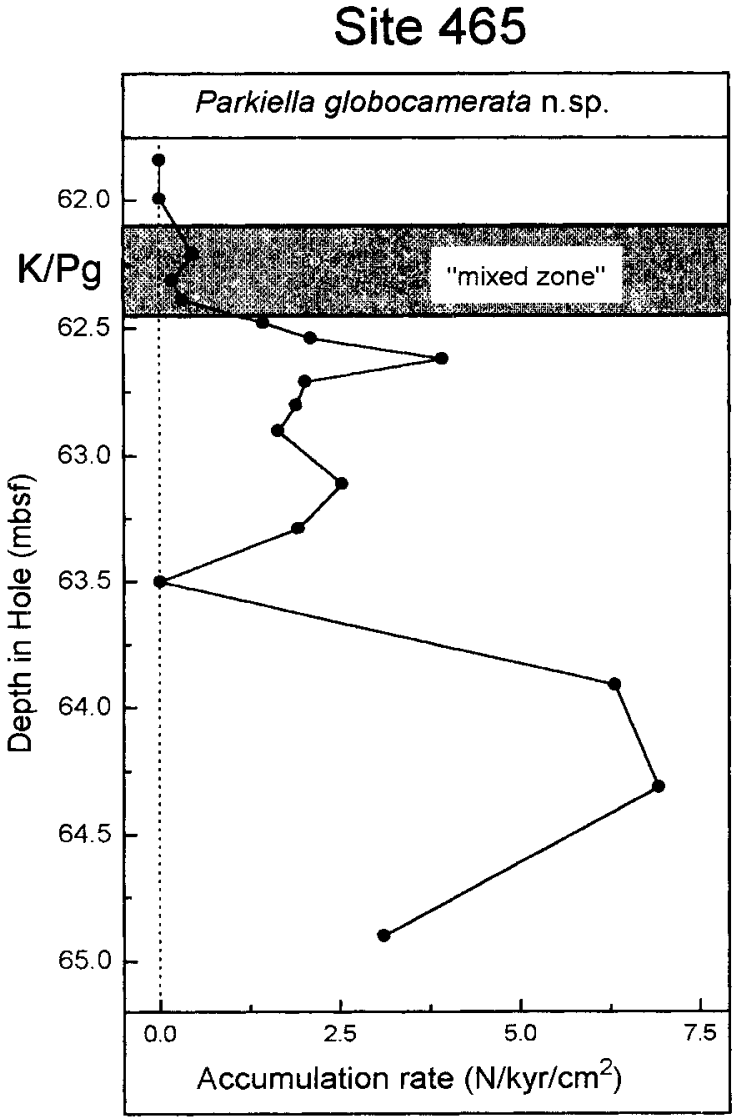

Fig. 5. Accumulation rates (in number of specimens $/ \mathrm{kyr} / \mathrm{cm}^{2}$ ) of $P$. globocamerata sp. nov, across the $\mathrm{K} / \mathrm{Pg}$ boundary within Core 3 at Hole $465 \mathrm{~A}$. Note the decrease in accumulation rates about $1 \mathrm{~m}$ below the $\mathrm{K} /$ $\mathrm{Pg}$ boundary and the lag in the decline across the boundary due to the interval of mixed Maastrichtian and Danian sediments.

poor foraminiferal preservation and Cores $8-9$ by exceptionally low dissolution (Fig. 3A) resulting in generally lower abundance of benthic foraminifera (Table 2).

Relative abundances of both species were determined in all samples, except samples no. 20 and no. 23, which were too poorly preserved to yield reliable foraminiferal counts. Parkiella angulocamerata sp. nov. fluctuated in relative abundances between 1.4 and $2.2 \%$ in Cores $12-10$, declined to $0 \%$ through Cores 9-7, and increased to $0.8 \%$ in Core 3, sample no. 21 (Fig. 3B). The proportion of $P$. globocamerata sp. nov. steadily increased in the lower part of Core 3 from 1.0 to $2.5 \%$. It suddenly declined to $0 \%$ between 63.91 and $63.50 \mathrm{mbsf}$, and above this interval it fluctuated between 0.5 and $1.3 \%$, with a single excursion to $1.9 \%$ in sample no. 8 .

Figure 5 illustrates the decline across the K/Pg boundary of $P$. globocamerata $\mathrm{sp}$. nov. in terms of accumulation rates (number of specimens $/ \mathrm{kyr} / \mathrm{cm}^{2}$ ) plotted against the depth in hole; note the lag in extinction just above the boundary due to the 'mixed zone of Maastrichtian and Danian sediments' of Thiede et al. (1981a). Accumulation rates for $P$. globocamerata sp. nov. declined from a mean Maastrichtian value of about 3.3 specimens $/ \mathrm{kyr} / \mathrm{cm}^{2}$ to about 0.3 in the 'mixed zone', and finally to zero above the 'mixed zone' in the lowermost Palaeocene (Fig. 5); note that the decrease in relative abundance above $63.5 \mathrm{mbsf}$ can also be observed in terms of accumulation rates. Employment of accumulation rates, a proxy for population density, enables us to conclude that the population of $P$. globocamerata sp. nov. indeed declined already below the $\mathrm{K} / \mathrm{Pg}$ boundary, i.e. before it became extinct, and that the simultaneous decrease in relative abundances of this species is not simply the result of a drastic increase in absolute abundance of other species within the benthic foraminiferal fauna.

The deep-sea benthic foraminiferal taxa that became extinct at the $\mathrm{K} / \mathrm{Pg}$ boundary were mainly endobenthic and they are assumed to have been generally more dependent on relatively high food-fluxes from the euphotic zone than epibenthic taxa (e.g. Thomas, 1990; Widmark \& Malmgren, 1992a). The extinction of $P$. globocamerata sp. nov. suggests that the species could have had an endobenthic mode of life and needed the relatively high food-fluxes that were provided by the primary producers in the eutrophic zone. When a large portion of these primary producers became extinct at the end of the Cretaceous, there was a devastating decline in food availability at deep seafloor and some eutrophic taxa, such as $P$. globocamerata sp. nov., could obviously not sustain the new, rougher conditions that emerged at the beginning of the Cenozoic. The decrease in both relative abundance and accumulation rate of the species observed about $1 \mathrm{~m}$ below the $\mathrm{K} / \mathrm{Pg}$ boundary at Site 465 may represent a prelude to the environmental disturbances that caused the biotic crisis at this transition.

The upper range limits of both species are well defined and documented at Site 465 . Both limits lie within Core 3, where sediment recovery and stratigraphic control are excellent. The restricted vertical distribution of both species makes them biostratigraphically useful and we propose that the interval between the LO (Last Occurrence) of $P$. angulocamerata sp. nov. and LO of $P$. globocamerata sp. nov. may indicate uppermost Cretaceous (upper Maastrichtian) in the tropical Pacific. This interval is roughly comparable to the calcareous nannofossil Micula prinsii Zone at Site 465 (see Fig. 6).

\section{BIOGEOGRAPHIC DISTRIBUTION AND ITS EVOLU- TIONARY IMPLICATIONS}

Widmark (1995) conducted a biogeographic survey encompassing terminal Cretaceous (Abathomphalus mayaroensis Zone) DSDP/ODP material from all over the world (Table 4). During this survey he encountered Parkiella globocamerata sp. nov. and $P$. angulocamerata sp. nov. (merged into his Buliminella? sp. A), only at one site, namely the Central Pacific Site 171 (Horizon Guyot), in addition to Site 465 (Tables 2, 4). Similarly, Douglas (1973) documented a form from Site 171 that he considered undescribed and called Buliminella sp. (his pl. 7, fig. 5), which also is identical to $P$. globocamerata sp. nov. The only information provided on the vertical distribution of Buliminella sp. ( $=P$. globocamerata sp. nov.) was its occurrence in Maastrichtian-?early Palaeocene strata at Site 171 (Douglas, 1973).

In the two samples available from Site 171 we encountered $P$. globocamerata $\mathrm{sp}$. nov. in the upper sample only, whereas $P$. angulocamerata sp. nov. was found in both samples; this corresponds to the stratigraphic succession we observed at Site 465. The relative abundances of Parkiella in the samples from 


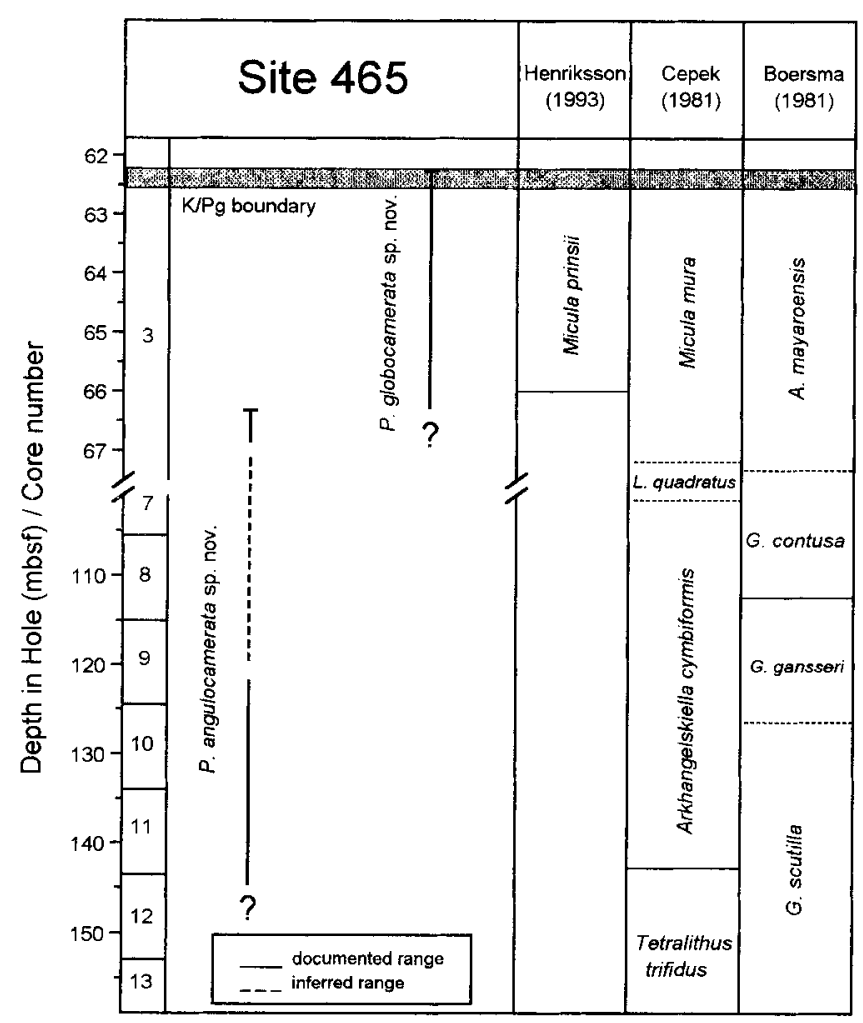

Fig. 6. Biostratigraphic summary of the vertical ranges of Parkiella spp. nov. and the Maastrichtian planktonic foraminifer (Boersma, 1981), and nannofossil (Cepek, 1981; Henriksson, 1993) zones recognized at Hole 465A. Last Occurrences (LOs) of both Parkiella species are well defined within Core 3 , which enables us to propose that the interval between the LO of $P$. globocamerata sp. nov. and LO of $P$. angulocamerata sp. nov. is indicative of upper Maastrichtian strata in the Central Pacific. This interval is slightly longer than the nannofossil Micula prinsii Zone identified at Site 465 by Henriksson (1993). Cores $4-7$ were omitted in the figure; vertical scale changes below Core 3 .

Site 171 are, however, significantly higher (6.6 and $8.9 \%$; see Table 2) than at Site 465. This may indicate that the palaeoenvironmental conditions at Site 171 were closer to the ecological optimum of the two species.

Both Sites 171 and 465 were located within the tropical Pacific sector of the Tethyan realm at the end of the Cretaceous (Fig. 1). Consequently, we can assume that during at least the Late Maastrichtian both $P$. globocamerata sp. nov. and $P$. angulocamerata sp. nov. were endemic to the Pacific realm. Other representatives of the genus Parkiella, including Parkiella gabonica, $P$. brevispira and $P$. mamelligera, have only been reported from shelf deposits from a restricted area in Gabon and Cameroon, West Africa (de Klasz \& Rérat, 1962; de Klasz et al., 1963; Seiglie et al., 1993).

Figure 7 illustrates the stratigraphic ranges of species referrable to the genus Parkiella. Two scenarios of the phylogenetic relationship between the geographically separated West African and Central Pacific stocks are possible: (1) a common ancestor of both stocks occurred (at the latest) in the Turonian; (2) the Central Pacific stock descended from $P$. mamelligera, the only representative of the 'older' West African stock that possessed spines (Fig. 7). A third alternative might be

\begin{tabular}{lll}
\hline Site & Ocean & Palaeolatitude* \\
\hline 47 Shatsky Plateau & Pacific & $20^{\circ} \mathrm{N}$ \\
171 Horizon Guyot & Pacific & $2^{\circ} \mathrm{N}$ \\
208 Lord Howe Rise & Pacific & $50^{\circ} \mathrm{S}$ \\
305 Shatsky Rise & Pacific & $20^{\circ} \mathrm{N}$ \\
465 Hess Rise & Pacific & $\mathbf{1 3}^{\circ} \mathrm{N}$ \\
10 N. American Basin & N. Atlantic & $29^{\circ} \mathrm{N}$ \\
111 Orphan Knoll & N. Atlantic & $41^{\circ} \mathrm{N}$ \\
384 J-Anomaly Ridge & N. Atlantic & $31^{\circ} \mathrm{N}$ \\
390 Blake Nose & N. Atlantic & $29^{\circ} \mathrm{N}$ \\
548 Goban Spur & N. Atlantic & $38^{\circ} \mathrm{N}$ \\
605 Off New Jersey & N. Atlantic & $36^{\circ} \mathrm{N}$ \\
20 Brazil Basin & S. Atlantic & $33^{\circ} \mathrm{S}$ \\
356 Sao Paulo Plateau & S. Atlantic & $32^{\circ} \mathrm{S}$ \\
363 Walvis Ridge & S. Atlantic & $29^{\circ} \mathrm{S}$ \\
516 Rio Grande Rise & S. Atlantic & $30^{\circ} \mathrm{S}$ \\
525 Walvis Ridge & S. Atlantic & $36^{\circ} \mathrm{S}$ \\
527 Angola Basin & S. Atlantic & $36^{\circ} \mathrm{S}$ \\
216 Ninetyeast Ridge & Indian & $37^{\circ} \mathrm{S}$ \\
217 Ninetyeast Ridge & Indian & $33^{\circ} \mathrm{S}$ \\
758 Ninetyeast Ridge & Indian & $35^{\circ} \mathrm{S}$ \\
689 Maud Rise & Southern & $70^{\circ} \mathrm{S}$ \\
698 Georgia Rise & Southern & $55^{\circ} \mathrm{S}$ \\
700 Georgia Basin & Southern & $55^{\circ} \mathrm{S}$ \\
738 Kerguclen Plateau & Southern & $62^{\circ} \mathrm{S}$ \\
750 Kerguelen Plateau & Southern & $44^{\circ} \mathrm{S}$ \\
\hline
\end{tabular}

Table 4. DSDP/ODP sites used in a biogeographic survey of late Maastrichtian benthic foraminifera by Widmark (1995). Localities (sites) where Parkiella was encountered are highlighted in bold. *Data on palaeolatitudes for the sites investigated were obtained (or estimated) from various DSDP and ODP reports.

that our new species were not at all related to the West African stock, and represented an independent lineage within the turrilinids (Fig. 7). In the latter case, $P$. globocamerata sp. nov. and $P$. angulocamerata sp. nov. should not be included in the genus Parkiella, but be considered as a separate deep-water genus morphologically parallel to shallow-water Parkiella.

\section{ACKNOWLEDGEMENTS}

We wish to thank Stefan Majoran, Björn Malmgren, and Robert Speijer, Göteborg University, for valuable suggestions on an early version of the article and to two anonymous reviewers for comments on the final manuscript. Smithsonian Institution, Washington, DC, USA, is acknowledged for depository facilities of the primary types through the courtesy of Brian Huber. Samples were provided by the ODP/DSDP. This study was supported by the Swedish Natural Science Research Council (NFR).

\section{Manuscript received January 1996 \\ Manuscript accepted March 1996}

\section{REFERENCES}

Berggren, W. A. 1984. Cenozoic deep water benthic Foraminifera: A review of major developments since Benthonics' 75. In Oertli, H. J. (Ed.) Benthos '83; Second International Symposium on Benthic Foraminifera (Pau, April 1983), Elf Aquitaine, Esso REP and Total CFP, Pau and Bordeaux, 1984, 41-43.

Berggren, W. A., Kent, D. V. \& Van Couvering, J. A. 1985. Jurassic to Paleogene: Part 2, Paleogene geochronology and chronostratigraphy. In Snelling, N. J. (Ed.) The Chronology of the Geological Record, Geological Society of London, Memoir, 10: 141-195.

Boersma, A. 1981. Cretaceous and Early Tertiary foraminifers from Deep Sea Drilling Project Leg 62 sites in the Central Pacific. Initial 


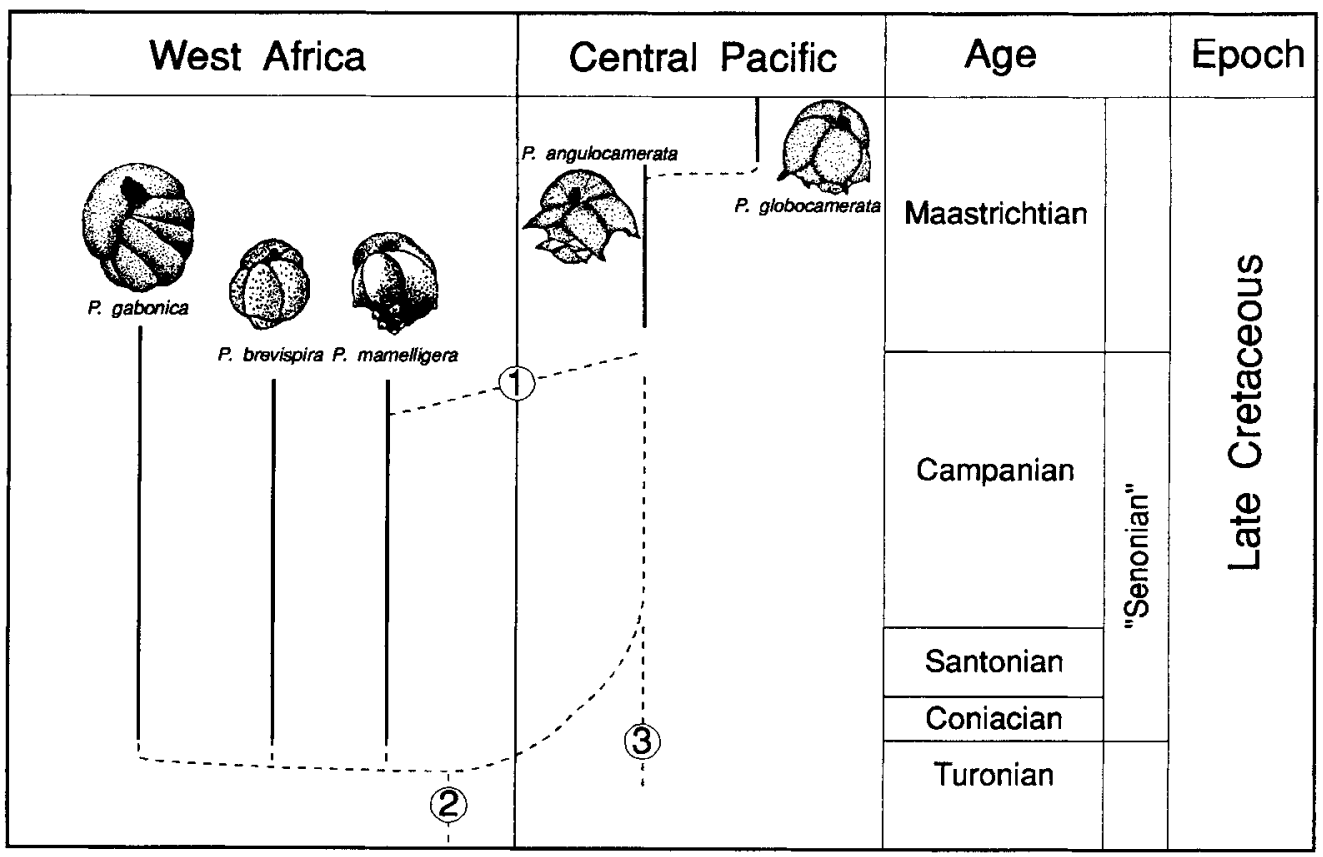

Fig. 7. Stratigraphic ranges of species assigned to the genus Parkiella (de Klasz \& Rérat, 1962; de Klasz et al., 1963; Seiglie et al., 1993; and this study). Possible evolutionary relationships between West African and Central Pacific representatives of Parkiella are illustrated by dashed lines. The Central Pacific stock may have evolved directly from one of the species of the West African stock, most probably from $P$. mamelligera (1); both Central Pacific and West African stocks could have descended from a common pre-'Senonian' ancestor (2); or, alternatively, the Central Pacific

Reports of the Deep Sea Drilling Project, 62: 377-396.

Boersma, A. \& Shackleton, N. J. 1981. Oxygen- and carbon-isotope variations and planktonic foraminifer depth habitats, Late Cretaceous to Paleocene, Central Pacific, Deep Sea Drilling Project Sites 463 and 465. Initial Reports of the Deep Sea Drilling Project, 62: 513-526.

Cepek, P. 1981. Mesozoic calcareous-nannoplankton stratigraphy of the central North Pacific (Mid-Pacific Mountains and Hess Rise), Deep Sea Drilling Project Leg 62. Initial Reports of the Deep Sea Drilling Project, 62: 397-418.

de Klasz, I., Magné, J. \& Rérat, D. 1963. Quelques formes nouvelles de Buliminidae caractéristiques du Crétacé supérieur du Gabon (Afrique Equatoriale). Revue de Micropaléontologie, 6: 145-152.

de Klasz, I. \& Rérat, D. 1962. Quelques nouvelles espèces du genre Buliminella du Crétacé supérieur du Gabon (Afrique Equatoriale). Revue de Micropaléontologie, 5: 69-74.

Douglas, R. G. 1973. Benthonic foraminiferal biostratigraphy in the central North Pacific Leg 17, Deep Sea Drilling Project. Initial Reports of the Deep Sea Drilling Project, 17: 607-696.

Douglas, R. G., \& Woodruff, F. 1981. Deep-sea benthic foraminifera. In Emiliani, C. (Ed.) The Oceanic Lithosphere, 7: 1233-1327.

Emiliani, C., Kraus, E. B. \& Shoemaker, E. M. 1981. Sudden death at the end of the Mesozoic. Earth and Planetary Science Letters, 55: $317-$ 334

Hansen, T., Ferrand, R. B., Montgomery, H. A., Billman, H. G. \& Bleckshmidt, G. 1987. Sedimentology and extinction patterns across the Cretaceous-Tertiary boundary interval in east Texas. Cretaceous Research, 8: 229-252.

Henriksson, A. S. 1993. Biochronology of the terminal Cretaceous calcareous nannofossil zone of Micula prinsii. Cretaceous Research, 14: $59-68$.

Kaiho, K. 1992. A low extinction rate of intermediate-water benthic foraminifera at the Cretaceous/Tertiary boundary. Marine Micropaleontology, 18: 229-259.

Malmgren, B.A. 1987. Differential dissolution of Upper Cretaceous planktonic foraminifera from a temperate region of the South Atlantic Ocean. Marine Micropaleontology, 11: 251-271.

Nomura, R. 1991. Paleoceanography of upper Maestrichtian to Eocene benthic foraminiferal asemblages at Sites 752,753 , and 754 , eastern
Indian Ocean. Proceedings ODP, Scientific Results, 121: 3-29.

Seiglie, G. A., Haman, D. \& Baker, M. B. 1993. Parkiella n.gen., a Late Cretaceous turrilinacid foraminifer from Gabon and Cameroon, West Africa. Micropaleontology, 39: 288-291.

Thiede, J., Vallier, T. L. et al. 1981a. Site 465. Initial Reports of the Deep Sea Drilling Project, 62: 199-282.

Thiede, J., Dean, W. E., Rea, D. K., Vallier, T. L. \& Adelseck, Ch. G 1981b. The geologic history of of the Mid-Pacific Mountains in the central North Pacific Ocean - A synthesis of deep-sea drilling studies. Initial Reports of the Deep Sea Drilling Project, 62: 1073-1120.

Thomas, E. 1990. Late Cretaceous through Neogene deep-sea benthic foraminifers (Maud Rise, Weddell Sea, Antarctica). Proceedings $O D P$, Scientific Results, 113B: 571-594.

Vallier, T. L., Rea, D. K., Dean, W. E., Thiede, J. \& Adelseck, Ch. G. 1981. The geology of Hess Rise, central North Pacific Ocean. Initial Reports of the Deep Sea Drilling Project, 62: 1031-1072.

Verhallen, P. J. J. M. 1986. Morphology and function of the internal structures of non-costate Bulimina. Proceedings of the Koninklijke Nederandse Akademie van Wetenschappen Series B, 89: 367-385.

Widmark, J. G. V. 1995. Multiple deep-water sources and trophic regimes in the latest Cretaceous deep sea: Evidence from benthic foraminifera. Marine Micropaleontology, 26: 361-384.

Widmark, J. G. V. \& Henriksson, A. S. 1995. The 'orphaned' agglutinated foraminifera - Gaudryina cribrosphaerellifera $\mathrm{n}$. $\mathrm{sp}$. from the Upper Cretaceous (Maastrichtian) Central Pacific Ocean. In Kaminski, M. A., Geroch, S. \& Gasinski, M. A. (Eds.) Proceedings of the Fourth International Workshop on Agglutinated Foraminifera, Krakow. Grzybowski Foundation Special Publication, 3: 293-300.

Widmark, J, G. V. \& Malmgren, B. A. 1992a. Benthic foraminiferal changes across the Cretaceous/Tertiary boundary in the deep-sea; DSDP Sites 525, 527, and 465. Journal of Foraminiferal Research, 22: 81-113.

Widmark, J. G. V. \& Malmgren, B. A. 1992b. Biogeography of terminal Cretaceous deep-sea benthic foraminifera from the Atlantic and Pacific oceans. Palaeogeography, Palaeoclimatology, Palaeoecology, 92: 375 405

Winterer, E. L., Ewing, J. I. et al. 1973. Site 171. Initial Reports of the Deep Sea Drilling Project, 17: 283-334. 